Saint Louis University School of Law Scholarship Commons

All Faculty Scholarship

3-1-2019

\title{
[Dis]integration: Second-Order Diversity and Schools
}

Anders Walker

Saint Louis University School of Law

Follow this and additional works at: https://scholarship.law.slu.edu/faculty

Part of the Civil Rights and Discrimination Commons, Constitutional Law Commons, and the Supreme Court of the United States Commons

\section{Recommended Citation}

Walker, Anders, [Dis]integration: Second-Order Diversity and Schools (March 1, 2019).

This Working Paper is brought to you for free and open access by Scholarship Commons. It has been accepted for inclusion in All Faculty Scholarship by an authorized administrator of Scholarship Commons. For more information, please contact erika.cohn@slu.edu, ingah.daviscrawford@slu.edu. 


\section{[DIS]INTEGRATION:}

\section{SECOND-ORDER DIVERSITY AND SCHOOLS}

\section{Anders Walker}

This article challenges the prevailing definition of diversity in schools. Borrowing from legal theorist Heather Gerken, it argues that diversity is best understood not simply as a rationale for creating integrated spaces, but also [dis]integrated ones, places where minority students and faculty can occupy majority positions, and are able to exercise majority control. Such spaces serve legitimate pedagogical goals that are different from those associated with statistical integration, and therefore warrant consideration by courts tasked with reviewing the use of race in university admissions.

\section{INTRODUCTION}

In her landmark article "Second-Order Diversity," Heather Gerken advances a new definition of diversity, one that emphasizes differentiation across institutions, rather than within them. ${ }^{1}$ As Gerken puts it, diversity within institutions, i.e. classrooms, constitutes only one way of thinking about the concept, what she calls "first order," while diversity across institutions constitutes a second way of thinking about the concept, or what she terms "second order."2 Second order diversity, continues Gerken, includes institutions where minorities are able wield majority power, giving them the opportunity to express themselves in ways not possible in conventional, majoritarian contexts. ${ }^{3}$ To illustrate, Gerken

\footnotetext{
- Lillie Myers Professor of Law and Professor of History, Saint Louis University. I would like to thank Juan Perea, Michael Kaufman, Sacha Coupet, Zelda Harris, Neil Williams, James Thuo Gathii, and the Loyola University Chicago School of Law workshop series for feedback on this draft.

${ }^{1}$ Heather Gerken, Second-Order Diversity, 118 HARV. L. REV. 1099 (2005).

${ }^{2} I d$.

${ }^{3} I d$.
} 
provides two examples: majority-minority electoral districts and majorityminority juries, both of which have garnered considerable critical attention. ${ }^{4}$

Missing from Gerken's analysis, perhaps for obvious reasons, are schools. ${ }^{5}$ Gerken does not apply her theory to schools because she is interested in telling a story that does not focus on "first order" diversity, or integration, and integration has been the dominant narrative of schools for the past half-century, since Brown v. Board of Education was decided in $1954 .^{6}$ However, the next half-century may bode different. Many schools in the United States, particularly urban schools, remain segregated. ${ }^{7}$ Further, advocates of school reform like the Alliance for Educational Justice, Black Youth Project 100, Forward through Ferguson, and Black Lives Matter have lost interest in desegregation as an imperative, lobbying instead for precisely the kind of majority-minority spaces that Gerken ties to second-order diversity. ${ }^{8}$ The same holds true for higher

\footnotetext{
${ }^{4}$ Jenny E. Carroll, The Jury as Democracy, 66 ALA. L. REV. 825 (2015); Doni Gewirtzman, Complex Experimental Federalism, 63 Buff. L. Rev. 241 (2015); Jeffrey Abramson, SecondOrder Diversity Revisited, 55 WM. \& MARY L. Rev. 739 (2014); Jason Soloma and Paula Hannford-Agor, The Civil Jury as a Political Institution Symposium: Introduction, 55 WM. \& MARY L. ReV. 715 (2014); Guy Uriel-Charles, Dissent, Diversity, and Democracy: Heather Gerken and the Contingent Imperative of Minority Rule, 48 TULSA L. REV. 493 (2013); Franita Tolson, Second-Order Diversity in Name Only: Sovereign Authority in Disaggregated Institutions, 48 Tulsa L. Rev. 455 (2013); Ilya Somin, Taking Dissenting by Deciding All the Way Down, 48 Tulsa L. Rev. 523 (2013); David Schleicher, From Here All-the-Way-down, or How to Write a Festschrift Piece, 48 TulSA L. ReV. 401 (2013); David Fontana, Relational Federalism: An Essay in Honor of Heather Gerken, 48 Tulsa L. Rev. 503 (2013); Adam B. Cox, The Temporal Dimension of Voting Rights, 93 VA. L. REV. 361 (2007).

${ }^{5}$ Gerken, Second-Order Diversity, 1107.

${ }^{6}$ Gerken, Second-Order Diversity, 1107; Charles J. Ogletree, JR. All Deliberate SpeEd: REFLECTIONS ON THE FIRST HALF CENTURY OF BROWN V. BOARD OF EDUCATION (2005); DERRICK BELl, SILENT COVENANTS: BROWN V. BOARD OF EDUCATION AND THE UNFULFILLED HOPES FOR RACIAL REFORM (2004); ROBERT J. COTTROL, ET AL. BROWN V. BOARD OF EDUCATION: CASTE, Culture, AND the Constitution (2003); JACK M. BALKIN, ET AL. WHAT BROWN V. BOARD OF EDUCATION SHOUld HAVE SAID: THE NATION's TOP LEgal EXPERTS REWRITE AMERICA's LandMark Civil Rights DeCision (2001); JAMES T. PATTERSON, BROWN V. BOARD OF EDUCATION: A CiVIL RightS MiLESTONE AND ITS TROUBLED LEGACY (2001).

${ }^{7}$ Charles J. Ogletree, Jr. All Deliberate Speed: Reflections on the First Half Century of Brown V. Board of EduCATION (2005); Derrick Bell, Silent Covenants: Brown V. BOARD OF EDUCATION AND THE UNFULFILLED HOPES FOR RACIAL REFORM (2004).

${ }^{8}$ Ferguson Commission, Forward through Ferguson: A Path toward Racial Equality (2015); The Movement for Black Lives, A Vision for Black Lives: Policy Demands for Black Power, Freedom, \& Justice (2016). That groups like Black Lives Matter and Forward through Ferguson choose not to focus on integration is intriguing, particularly given the decades of social science research indicating that integration benefits minority children. See, e.g. Michael J. Kaufman, PICS in Focus: A Majority of the Supreme Court Reaffirms the Constitutionality of Race-Conscious School Integration Strategies, 35 HaStings Const. L. Q. 1, 21 n. 107 (2017).
} 
education, both in the context of historically black colleges and universities (HBCUs), which have traditionally stressed the value of majority black space, as well as majority white schools, where minority students have called for their own organizations, their own events, and in some cases even their own academic departments. ${ }^{9}$

Taking Brown's denouement as a cue, this article proposes second-order diversity as a new frame for thinking about education in America. It proceeds in three parts. First, it suggests that diversity has always existed in tension with statistical integration, and that the Supreme Court's elevation of diversity to the level of a compelling interest was a reaction to, rather than a fulfillment of, the assimilationist ethos in Brown. Second, the article applies Gerken's analytic to primary and secondary schools, suggesting that it is actually more attuned to the unique problems facing majority-minority urban school districts and the unique needs of majority-minority urban students. ${ }^{10}$ Finally, this article suggests that Gerken's theory provides us with a new way of thinking about diversity in higher education as well, one that privileges HBCU's and supports the defense of black

\footnotetext{
${ }^{9}$ The Movement for Black Lives, A Vision for Black Lives: Policy Demands for Black Power, Freedom, \& Justice (2016); Susan Olzak \& Nicole Kangas, Ethnic, Women's, and African American Studies Majors in U.S. Institutions of Higher Education 81 SocIOLOGY OF EDUCATION 163 (2008); Henry Louis Gates, Jr. Black Studies at the Crossroads: A Discussion with Henry Louis Gates Jr. 55 JOURNAL OF BLACKS IN HIGHER EDUCATION 58 (2007).

${ }^{10}$ The approach taken in this article presumes that school district boundaries are relatively inviolable, and that education reformers stand a better chance of success by focusing on the needs of children within districts, including majority-minority districts, than expending valuable political capital trying to redraw district lines, whether by mobilizing voters, or lobbying courts. Christopher Suarez argues for a different approach, holding that minority students stand to benefit from going to school with majority peers, and that school district lines should be redrawn across the country to ensure that no district boasts more than $60 \%$ low income students, and most districts boast no more than $\% 40$ low income students. This approach presumes a major change in federal law, one that a Gerkenian second-order diversity analysis does not. See e.g. Christopher A. Suarez, Democratic School Desegregation: Lessons from Election Law, 119 PenN ST. L. ReV. 747 (2015). Suarez hinges his theory on the value of first-order diversity, not second, a position that remains popular among many academics. See, e.g. Derek W. Black, Middle-Income Peers as Educational Resources and the Constitutional Right to Equal Access, 53 B.C.L. REv. 373, 409 (2012); Michael J. Kaufman, PICS in Focus: A Majority of the Supreme Court Reaffirms the Constitutionality of Race-Conscious School Integration Strategies, 35 HASTINGS CONST. L.Q. 1 (2007); Nancy Conneely, Note, After PICS: Making the Case for Socioeconomic Integration, 14 TEX. J. C. L. \& C.R. 95, 115 (2008), Brief of 553 Social Scientists as Amici Curiae in Support of Respondents at 6, Parents Involved in Cmty. Sch. v. Seattle Sch. Dist. No. 1, 551 U.S. 701 (2007)(Nos. 05-908, 05-915), 2006 WL 2927079).
} 
space, Black Studies, and the use of race in university admissions at majority white institutions.

Black Studies tends not to be mentioned in constitutional debates over diversity, but should. Though open to white students, most Black Studies programs attract more African American students than white, meaning that cuts in black enrollment could lead to cuts in programs, including the termination of programs. According to Harvard University, for example, black enrollment would drop from $14 \%$ to $6 \%$ were race no longer used in admissions. ${ }^{11}$ Were this number insufficient to support a Black Studies major, that program may be terminated, meaning that court orders on diversity may have a direct link to college curricula, boosting some departments and gutting others.

As much as opponents of diversity may be motivated by a sense of fairness, in other words, they may not realize the pedagogic implications of occluding race in university admissions over the long term. If a particular racial group or groups outperforms all other groups, for example, those groups could theoretically capture an institution. Not only would first-order diversity stand to suffer under such a circumstance, but second-order diversity would as well, including the ability of colleges to freely choose their own academic path.

\section{The Brown Diversity Myth}

Central to the case for diversity is pedagogy, the idea that students stand to learn from difference. ${ }^{12}$ This was the argument that the Supreme Court made when it first elevated diversity to the level of a compelling interest in 1978, and it remains the argument for diversity today. ${ }^{13}$ As Harvard University put it in December 2018, “intellectual transformation is deepened and conditions for social

\footnotetext{
${ }^{11}$ Harvard's Proposed Findings of Fact and Conclusions of Law, Students for Fair Admissions (SFFA) v. Harvard College, 1:14-cv-14176-ADB, 49.

${ }^{12}$ Harvard's Proposed Findings of Fact and Conclusions of Law, Students for Fair Admissions (SFFA) v. Harvard College, 1:14-cv-14176-ADB, 4.

${ }^{13}$ Regents of Univ. of California v. Bakke, 438 U.S. 265, 312 (1978)("The atmosphere of 'speculation, experiment, and creation' - so essential to the quality of higher education - is widely believed to be promoted by a diverse student body." Citing Bowen, Admissions and the Relevance of Race, Princeton Alumni WeEkLy 7, 9 (Sept. 26, 1977))
} 
transformation are created" whenever students "come from different walks of life."

This was not, however, the Supreme Court's rationale for integration. Brown v. Board of Education rejected the idea that white students might learn from their black peers, positing instead that African American students were damaged and needed help. ${ }^{15}$ Footnote 11 of the ruling cited a study by a Swedish sociologist named Gunnar Myrdal who declared that black America was a "pathological form" of America generally, and that the solution to America's racial "dilemma," was full assimilation of African Americans into mainstream white society, at the cost of black identity. ${ }^{16}$ "We assume," wrote Myrdal, "that it is to the advantage of the American negroes as individuals and as a group to become assimilated into American culture, to acquire the traits held in esteem by the dominant white Americans."17 To prove his point, Myrdal included a chapter by a University of Chicago graduate student named Arnold Rose, who declared cultural "assimilation" to be a "central element" of the "American creed," a point underscored by the "melting pot" ideal in which "diverse ethnic groups" had immigrated to the United States and "abandon[ed]" their "cultural particularities." 18 Excluded from this process, argued Rose, were African Americans, who had not been "allowed to assimilate," but rather had been kept apart by prohibitions against intermarriage and laws that "segregated" the races. 19 Shut out of the American melting pot, blacks "developed" their own "separate institutions" including their own "American Negro culture."20

\footnotetext{
${ }^{14}$ Harvard's Proposed Findings of Fact and Conclusions of Law, Students for Fair Admissions (SFFA) v. Harvard College, 1:14-cv-14176-ADB, 4.

${ }^{15}$ Brown v. Board of Education, 347 U.S. 483, 494 fn 11 (1954). GUNNAR MYRDAL, AN American Dilemma Vol. II: The Negro Problem And Modern Democracy 927 (1944, New Brunswick: Transaction, 1996).

${ }^{16}$ Gunnar Myrdal, An American Dilemma Vol. II: The Negro Problem and Modern DEMOCRACY 927 (1944, New Brunswick: Transaction, 1996).

${ }^{17}$ Gunnar Myrdal, An American Dilemma Vol. II: The Negro Problem and Modern DEMOCRACY 927 (1944, New Brunswick: Transaction, 1996).

${ }^{18}$ Gunnar Myrdal, An American Dilemma: The Negro Problem ANd Modern Democracy, Volume II (1944, New Brunswick: Transaction, 2003), 927.

${ }^{19}$ Gunnar Myrdal, An American Dilemma: The Negro Problem and Modern Democracy, Volume II (1944, New Brunswick: Transaction, 2003), 928.

${ }^{20}$ Gunnar Myrdal, An American Dilemma: The Negro Problem and Modern Democracy, Volume II (1944, New Brunswick: Transaction, 2003), 928.
} 
Black culture did not - to Rose's mind - possess its own inherent value or worth, but rather represented a "distorted" or "pathological" version of the "general American culture." 21 To bolster this claim, Rose referenced a series of factors, including a study of the black family by African American sociologist E. Franklin Frazier, noting that "family disorganization" was high in black communities, as evidenced by the fact that "Negroes have about eight times as much illegitimacy as native whites." 22 While Frazier's actual argument was that black illegitimacy rates varied based on geography and therefore reflected "social environment" more than culture, Rose hammered away at black culture, even referencing the "emotionalism of the Negro church" to demonstrate that black culture was less developed. ${ }^{23}$ To Rose's mind, charismatic religion only further compounded "the insufficiency and unwholesomeness of Negro recreational activity," "the plethora of [inferior] Negro social organizations," and the tendency of African Americans to support "cultivation of the arts to the neglect of other fields." 24 Oddly oblivious to the value that many found in these categories, Rose jumped to endorse assimilation, arguing that it would be to the "advantage" of blacks in America "to become assimilated into American culture" and to "acquire the traits held in esteem by the dominant white Americans." 25 Though Rose paid lip service to the basic premise of anthropology that "all cultures may be good," he posited that "here, in America," white culture was "highest" and that any minority group "not strong enough to change it" should assimilate into that culture. $^{26}$

Myrdal endorsed Rose's conclusions, arguing that the chapter represented a "fresh approach" to one of the central premises of the study, namely that white

\footnotetext{
${ }^{21}$ Gunnar Myrdal, An AmericAn Dilemma: The Negro Problem AND Modern Democracy, Volume II (1944, New Brunswick: Transaction, 2003), 928.

22 Gunnar Myrdal, An American Dilemma: The Negro Problem And Modern Democracy, Volume II (1944, New Brunswick: Transaction, 2003), 933.

${ }^{23}$ Daryl Michael Scott, ConTEMPT \& Pity: Social PoliCY AND THE IMAGE OF THE DAMAGED BLACK PSYCHE, 1880-1996 (1997), 44.

${ }^{24}$ Gunnar Myrdal, An AmericAn Dilemma: The Negro Problem And Modern Democracy, Volume II (1944, New Brunswick: Transaction, 2003), 928-29.

${ }^{25}$ Gunnar Myrdal, An AmericAn Dilemma: The Negro Problem AND Modern DemocraCy, Volume II (1944, New Brunswick: Transaction, 2003), 929.

${ }^{26}$ Gunnar Myrdal, An AMERICAN Dilemma: The Negro Problem AND Modern Democracy, Volume II (1944, New Brunswick: Transaction, 2003), 929.
} 
culture was the "highest" form of culture in America and that African Americans needed to "acquire" as many "traits" from the "surrounding white culture" as possible. ${ }^{27}$

Not everyone agreed. Ralph Ellison, a black writer from Oklahoma, criticized Myrdal's view that "the Negro's entire life" was simply a reaction to the "dominant white majority." How "can a people," asked Ellison, "live and develop for over three hundred years simply by reacting?"28 Reluctant to view black culture as pathological, Ellison challenged Myrdal's claim that white culture was somehow better, noting for example that "radio advertising," "Hollywood," and "lynching" were all products of white culture, and that blacks stood to gain little from embracing such phenomena. "Why, if my culture is pathological," asked Ellison, "must I exchange it for these?"29 Instead, Ellison posited that precisely because blacks were shut out of white society, they had gained a healthy perspective on white "pathologies," developing instead their own culture that boasted "much of great value" and "richness." 30 Rather than assimilate blacks into white society, in other words, Ellison recommended a change in the "basis of society" that would improve people's lives but not erase their cultural identity. "In Negro culture," he concluded, "there is much of value for America as a whole." ${ }^{31}$

Ellison's critique fell on deaf ears. In 1947, NAACP attorney Thurgood Marshall cited An American Dilemma in a brief filed on behalf of Ada Lois Sipuel, an aspiring law student denied entry to the University of Oklahoma Law School on account of her race. ${ }^{32}$ He cited it again in 1952 when the NAACP brought a direct challenge to segregated schools, resting its claim on the notion

\footnotetext{
${ }^{27}$ Walter Jackson, GuNNAR MyRDAL AND AMERICA's CONSCIENCE: SOCIAL ENGINEERING AND RACIAL LIBERALISM, 1938-1987 (1990), 170-71.

${ }^{28}$ Ralph Ellison, "An American Dilemma: A Review," in Shadow and Act (1953, New York: Vintage, 1995), 315.

${ }^{29}$ Ralph Ellison, "An American Dilemma: A Review," in Shadow and Act (1953, New York: Vintage, 1995), 316.

${ }^{30}$ Ralph Ellison, "An American Dilemma: A Review," in Shadow and Act (1953, New York: Vintage, 1995), 316.

${ }^{31}$ Ralph Ellison, "An American Dilemma: A Review," in Shadow and Act (New York: Random House, 1964), 317.

${ }^{32}$ Richard Kluger, Simple Justice: The History of Brown v. BoARd of EduCATION AND BLACK AMERICA's STRUGGLE FOR EQUALITY (1977), 259.
} 
that not only did Jim Crow fail to encourage black development, but it caused tangible, psychological harm to black children. ${ }^{33}$ NAACP attorneys Thurgood Marshall, Robert L. Carter, Oliver Hill and Spottswood Robinson all cited the "Carnegie-Myrdal study," in a brief filed on behalf of Dorothy E. Davis and other black students in Virginia, challenging segregated schools in that state. ${ }^{34}$ That case would later be consolidated into three other cases, from South Carolina, Delaware and Kansas, to form the basis of Brown v. Board of Education of Topeka, which the Court decided on May 17, 1954.

In its opinion, the Court cited Myrdal to help demonstrate that segregation violated equal protection because it harmed black youth, regardless of whether schools were equally funded. ${ }^{35}$ Even if black schools were the same materially, reasoned Chief Justice Earl Warren, they still damaged black children, because segregation itself generated "a feeling of inferiority" that was unlikely to ever be "undone.",36 This was true, maintained the Court, even if schools were "equalized, with respect to buildings, curricula, qualifications and salaries of teachers and other "tangible factors.", 37

Not everyone concurred. Prominent black writer Zora Neale Hurston wrote a letter to the Orlando-Sentinel decrying the ruling. "How much satisfaction can I get," queried Hurston in August 1955, "from a court order for somebody to associate with me who does not wish me near them?" Hurston posed the question from her coastal home in Eau Gallie, Florida, writing a letter to the Orlando-Sentinel that would become one of the most notorious critiques of Brown in the 1950s. ${ }^{38}$ "I regard the U.S. Supreme Court as insulting rather than

\footnotetext{
${ }^{33}$ Davis v. County School Board of Prince Edward County, No. 3, Supreme Court of the United States, October Term, 1954, July 12, 1952 Initial Brief: Appellant-Petitioner, 19, n 4.

${ }^{34}$ Davis v. County School Board of Prince Edward County, No. 3, Supreme Court of the United States, October Term, 1954, July 12, 1952 Initial Brief: Appellant-Petitioner, 19, n 4.

${ }^{35}$ Brown, 347 U.S. at 494.

${ }^{36}$ Brown, 347 U.S. at 494.

${ }^{37}$ Brown, 347 U.S. at 492.

${ }^{38}$ Newspapers across the South reprinted Hurston's letter. William W. Taylor, Special Counsel to North Carolina's Advisory Committee on Education wrote Hurston on Aug. 25, 1955, requesting permission to "reprint" the letter in "pamphlet form" for distribution around the state. "We believe that it might be of great help in our efforts to find a reasonable solution to the problem now facing the public schools," wrote Taylor, "and that it is an excellent implementation of the recent policy address of the Governor of this State." William W. Taylor, Jr. to Zora Neale
} 
honoring my race," she declared, balking at the presumption that African Americans suffered damage simply because they lacked white contact. Blacks wanted opportunity and resources, she argued, not intimacy. "If there are not adequate Negro schools in Florida," asserted Hurston, "and there is some residual, some inherent and unchangeable quality in white schools, impossible to duplicate anywhere else, then I am the first to insist that Negro children of Florida be allowed to share this boon. But if there are adequate Negro schools and prepared instructors and instructions, then there is nothing different except the presence of white people." ${ }^{39}$

Hurston's critique came on the tail end of a long career that celebrated black cultural achievement, often ranking it above white. During the Harlem Renaissance, for example, Hurston wrote stories about the spiritual strength of black communities, their resilience, and also their creative self-expression. By contrast, she cast white society as violent and racist, a point she made clear in a 1948 novel styled Seraph on the Suwanee, about a family of white "piney-wood crackers" who brutalize one another in North Florida. ${ }^{40}$ Hurston's critique of mainstream white culture echoed Ellison's, and informed her anger at Brown, a decision that struck her as dismissive - even hostile - to the idea of racial diversity.

Black intellectuals were not, however, Brown's only cultural critics. White southerners like Eudora Welty, Harper Lee, and Robert Penn Warren also reacted negatively to the ruling, particularly its assumption that African American culture was pathological. Lee articulated this view in a story about a white lawyer who defends a black client in Alabama in the 1930s, showing how the attorney's servant Calpurnia boasted her own institutions, traditions, even culture - all to the

Hurston, August 25, 1955, Zora Neale Hurston Correspondence, Box 1, Zora Neale Hurston Papers, Special Collections, University of Florida, Gainesville, Florida. See also Virginius Dabney to Martin Andersen, Aug. 15, 1955 (discussion the decision to reprint Hurston's letter in the Richmond Times-Dispatch) and Burke, Kuipers \& Mahoney to Martin Andersen, Oct. 19, 1955 (discussing Hurston's letter in the Dallas News), Zora Neale Hurston, Correspondence, Box 1, Zora Neale Hurston Papers, Special Collections, University of Florida, Gainesville, Florida.

${ }^{39}$ Zora Neale Hurston to Editor (Orlando Sentinel), Aug. 11, 1955, reprinted in Zora Neale Hurston: A Life in Letters, Carla Kaplan, ed. (New York: Doubleday, 2002), 738-39.

${ }^{40}$ Zora NeAle Hurston, SERAPH ON THE Suwanee (1948). 
acclaim of the lawyer, Atticus Finch, and his children, Scout and Jem. ${ }^{41}$ Eudora Welty did the same in a short story about a white doctor who finds spiritual renewal in a black community. ${ }^{42}$ Robert Penn Warren concurred, first by defending Jim Crow as a refuge for black art in 1929, and then by casting Brown as an effort to render all southerners, white and black, "exactly alike."43

Warren expressed this position to Ralph Ellison during an interview at the American Academy in Rome in 1956, even suggesting that something authoritarian lurked behind the Court's mandate in Brown, an effort not simply to achieve legal equality, but to eradicate diversity. "What I'm trying to say is this," he explained, "A few years ago I sat in a room with some right-thinking friends, the kind of people who think you look in the back of the book for every answer attitude A for situation A, attitude B for situation B, and so on for the whole damned alphabet. It developed that they wanted a world where everything is exactly alike and everybody is exactly alike. They wanted a production belt of human faces and human attitudes." Ellison concurred. "Hell, who would want such a world?"44

That Ellison shared Warren's concern that "right-thinking" liberals might threaten diversity was significant. He harbored no love for segregation, or white southerners, a point he had made clear in a letter that he wrote to fellow black writer Albert Murray while in Rome. "[W]e're trying hard as hell to free ourselves," he explained to Murray, "so that when we got the crackers off our back we can discover what we (Moses) really are and what we really wish to preserve out of the experience that made us." "Moses" was Ellison's euphemism for African Americans, a group that he believed possessed valuable information and important traditions, forged in the violent crucible of Jim Crow.

"[C]rackers," by contrast, were whites, whose culture left much to be desired. To jettison black traditions for "crackerdom," as Ellison called white

\footnotetext{
${ }^{41}$ HarPer LeE, To Kill a Mockingbird (1960).

${ }^{42}$ Eudora Welty, "The Demonstrators," The New YoR Ker, Nov. 26, 1966, p. 56.

${ }^{43}$ Robert Penn Warren, "The Briar Patch," in I'Ll TAKe My StAnd (John Crowe Ransom, ed., 1930).

${ }^{44}$ Ralph Ellison, Eugene Walter, and Robert Penn Warren, "Warren on the Art of Fiction," Paris Review (1957), reprinted in Floyd C. Watkins, et al, eds. Talking with Robert Penn Warren (Athens: University of Georgia Press, 1990), 47.
} 
society, was undesirable, leading him to side with Warren, cracker though he was, on the issue of diversity or, what Warren termed "pluralism." "I want variety and pluralism," explained Warren to Ellison, and "appreciation," appreciation of the differences and divisions in America, the divergent traditions and cultures that enriched the national tapestry. "Man is interesting in his differences," declared Warren, a point that did not preclude reform, to be sure, but placed restrictions on it, particularly on grand schemes like integration, which sought cultural assimilation. Warren acknowledged to Ellison that "some sort of justice and decency" should be achieved, maybe even with government help, but not at the cost of diversity. Government campaigns to achieve justice by eliminating diversity struck Warren as fundamentally wrong, bids to legislate "undifference." "I feel pretty strongly about attempts to legislate undifference," explained Warren to Ellison, "That is just as much tyranny as trying to legislate difference." 45

The conversation between Ellison and Warren hinted at a shared vision of American pluralism. Both writers prized difference, praised diversity, and viewed America as a culturally diverse nation, a position that led them to question the assimilationist logic behind Brown. Both also harbored doubts about the feasibility, nay desirability, of big government solutions to social problems. This was Warren's point in Rome, which Ellison agreed with, and it was a point that both writers had confronted in their work: Warren in All the King's Men and Ellison in Invisible Man. In the latter, which earned the National Book Award in 1953, Ellison's narrator clashes with communists who preach equality but exploit blacks. Warren portrayed a similarly cynical tale in his Pulitzer prize-winning novel All the King's Men, about a southern demagogue who rises to power on promises of ending poverty, but ends up centralizing power around himself. Both Warren and Ellison seemed to recognize that aspirational politics might open the door to frightening, perhaps even totalitarian tendencies.

Brown, 347 U.S. at 494. Library, 2000), 117; Ralph Ellison to Albert Murray, Feb. 4, 1952, in Trading Twelves: The Selected Letters of Ralph Ellison and Albert Murray, eds. Albert Murray and John F. Callahan (New York: Modern Library, 2000), 29. Ralph Ellison, Eugene Walter, and Robert Penn Warren, "Warren on the Art of Fiction," Paris Review (1957), reprinted in Floyd C. Watkins, et al, eds. Talking with Robert Penn Warren (Athens: University of Georgia Press, 1990), 47. 
Arguably no southerner feared authoritarianism and celebrated pluralism more than Lewis F. Powell, Jr. - a lawyer from Richmond roughly the same age as Warren and Ellison who rose to the United States Supreme Court in 1972. Born in Suffolk, Virginia in 1907, Powell grew up in the segregated South, fought in World War II, and came to believe that the greatest threat to American life was not inequality - which he had become inured to in Virginia - but the centralization of state power. Powell witnessed the horror of such totalitarian power up close during World War II, and again in 1958, when he traveled with the American Bar Association to the Soviet Union. In a private journal that he kept during his trip, Powell noted the alarming degree to which the Russians controlled thought and punished dissenting ideas. Communism, he came to believe, was fundamentally unfree, a propaganda-driven system that tolerated no political or ideological independence; a system that burned books and banned speech, all in the name of equality. ${ }^{46}$

Soviet aspirations of creating a classless society, in Powell's mind, were closely tied to its reliance on aggressive government measures: five year plans, purges, and so on. By contrast, America's commitment to liberty struck Powell as inextricably linked to constraints on government power that created zones of freedom, places where there could be vast disparities in wealth, in education, and even in political viewpoints, disparities that were themselves expressions of diversity, or what he liked to term pluralism. In one of his most startling opinions, for example, Powell declared that inequality in public school funding contributed to "pluralism" by preventing the centralization of education because it protected local schools from centralized control, even as it pressed schools in lowincome districts to "innovate." 47

Powell elaborated on this view in Regents v. Bakke, the opinion that declared diversity in university admissions to be a compelling interest. ${ }^{48}$ There,

\footnotetext{
${ }^{46}$ Anders Walker, Diversity's Strange Career: The Racial Pluralism of Lewis F. Powell, Jr. 50 SANTA Clara L. REV. 647 (2010).

${ }^{47}$ San Antonio v. Rodriguez, 411 U.S. 1 (1973).

${ }^{48}$ Regents v. Bakke, 438 U.S. 265 (1978).
} 
Powell explained that all America was made up of minorities, even whites, many of whom had suffered discrimination at the hands of the state. To ascertain who had suffered more, he argued, was impossible, meaning that any program aimed at helping a racial group violated equal protection. However, schools could consider race for the purpose of diversity, provided they had a sincere pedagogical reason for doing so. This meant that some schools might strive for a heavy black presence in order to develop black leaders, much like Wellesley, Smith, and Mount Holyoke sought to develop women leaders. Or, some schools might strive for classes that included students of a variety of races, whether to forge interracial understanding, or to deconstruct the notion of race itself. It didn't really matter to Powell what schools wanted to do, so long as different schools were allowed to do different things, and the state did not impose centralized mandates.

Of course, schools could not exclude all students of a particular race, per Brown, but Powell did not think that Brown went much beyond that. ${ }^{49}$ As early as 1970, for example, he argued that Brown called for the removal of overt racial classifications, nothing more. ${ }^{50}$ As he explained it in a brief filed on behalf of Charlotte, North Carolina, no state could require racial segregation, but if racial segregation happened voluntarily, say as a consequence of residential patterns, it was not a violation of equal protection. ${ }^{51}$ Were the Court to rule differently, he warned, negative consequences might ensue. ${ }^{52}$ For example, if Charlotte was required to adopt aggressive measures like busing to achieve racial integration, or "balance," white families would leave. ${ }^{53}$ Powell warned that this was already happening in Richmond, where he lived, and that courts should stem the bleeding by narrowly interpreting Brown. ${ }^{54}$

\footnotetext{
${ }^{49}$ ANDERs WALKER, THE BURNing HouSE: Jim Crow AND THE MAKING OF MODERN AMERICA 181 (2018).

${ }^{50} I d$.

${ }^{51} I d$.

${ }^{52} I d$.

${ }^{53} I d$.

${ }^{54} I d$.
} 
II. Second-Order Diversity and Lower Education

Powell's prediction that racial balance might lead to white flight proved prophetic. Across America, white urbanites left urban centers to escape busing, prompting a demographic shift that transformed American life. ${ }^{55}$ As whites left cities, they boosted suburban development and drained urban coffers, leaving African Americans isolated and abandoned in crumbling inner-city cores. ${ }^{56}$ Whites also left the Democratic Party, opting for a grassroots, suburban conservatism that transformed American politics, blaming the urban crisis on Lyndon Johnson's "War on Poverty" and "Great Society" programs, meanwhile lobbying for lower taxes, less entitlements, and local schools. ${ }^{57}$

This affected law as well. Anti-busing sentiment helped elect California conservative Richard Nixon to the presidency in 1972, and Nixon promptly appointed Powell to the Supreme Court. ${ }^{58}$ Once there, Powell helped construct a firewall around suburban school districts, all in the name of local control and institutional pluralism. ${ }^{59}$ This story, often told in terms of declension, reversed the hope that Brown might achieve racial balance in American schools, and in many cases resulted in urban re-segregation. ${ }^{60}$

But with black schools came black space. Though Heather Gerken has not applied her theory of second-order diversity to schools, school reformers have begun to focus less on schemes aimed at increasing integration, and more on providing African American children with the education they need, independent

\footnotetext{
55 Thomas J. Sugrue, The Origins Of the URban CRisis: RaCe AND INEQUALity IN Postwar Detroit (1996); Kevin M. Kruse, White Flight: Atlanta And the MaKing OF Modern CONSERVATISM (2005).

${ }^{56} I d$.

${ }^{57}$ Lisa McGirr, Suburban Warriors: The Origins of the NeW AMERICAN Right (2001): Kenneth T. JACKSON, Crabgrass Frontier: The Suburbanization of the United States (1985).

58 Matthew F. Delmont, Why Busing Failed: Race, Media, and the National Resistance

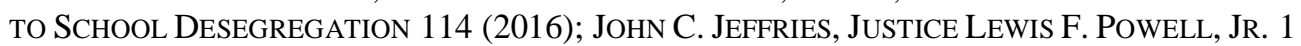
(2001).

59 Anders WAlKer, The Burning House: Jim CROW AND THE MAKING OF Modern AmeriCA 175-196 (2018).

${ }^{60}$ JAmes T. PATterson, Brown v. BoARd of EduCATiOn: A CiVil Rights Milestone AND its TROUBLED LEGACY 191 (2001).
} 
of whites. ${ }^{61}$ This approach invites us to reconsider whether the benefits that Gerken ascribes to second-order diversity might also be applied to schools, something that no one - including Gerken herself - has thought to ask. However, they include: 1) whether majority black schools give African Americans control of their own institutions, 2) whether they provide an opportunity to turn the tables on majorities, 3) whether they give minorities the freedom to dissent by deciding policy, and finally, 4) whether majority black school systems provide room to experiment with, or "cycle" through, approaches to achieving educational goals for black children that would not be available in majority white settings. ${ }^{62}$

Already, examples of Gerken's frame are emerging in school districts across the country that have grown tired of expending resources on integration and begun focusing instead on creating "Afrocentric" schools. ${ }^{63}$ For example, New York City boasts a half-dozen Afrocentric schools that enroll roughly 2,300 children, staffed largely by African American teachers and administrators who are able to "control" the institution, and "dissent by deciding" both the curriculum and modes of discipline, both problems for African American students in majority white schools. ${ }^{64}$ For example, Afrocentric schools are able to "focus on black culture in literature, history, and art classes," without fearing majority white backlash. ${ }^{65}$ Black teachers and parents are also able to "turn the tables" on majority white institutions, many of which single out black students for disproportionate punishment, underestimate black intellectual potential, and alienate black students socially due to implicit peer group bias. ${ }^{66}$ Precisely because few white students apply to enter Afrocentric schools, in other words,

${ }^{61}$ Eliza Shapiro, “I Love My Skin!” Why Black Parents are Turning to Afrocentric Schools, N.Y. TIMES, Jan. 8, 2019, A1, A24.

${ }^{62}$ Gerken, Second-Order Diversity.

${ }^{63}$ Eliza Shapiro, "I Love My Skin!” Why Black Parents are Turning to Afrocentric Schools, N.Y. TiMES, Jan. 8, 2019, A1, A24.

${ }^{64}$ Eliza Shapiro, "I Love My Skin!” Why Black Parents are Turning to Afrocentric Schools, N.Y. Times, Jan. 8, 2019, A1, A24.

${ }^{65}$ Eliza Shapiro, "I Love My Skin!” Why Black Parents are Turning to Afrocentric Schools, N.Y. TiMES, Jan. 8, 2019, A1, A24.

${ }^{66}$ Denise C. GotTfredson, Schools And Delinquency (2001); Karl L. Alexander, et al. School Performance, Status Relations, and the Structure of Sentiment: Bringing the Teacher Back In, 52 AMERICAN Sociological ReVIEW, 665, 680 (1987); DelBeRt S. ElliotT, ET AL. Violence IN AMERICAN SCHOOLS (1998). 
said schools are able to "cycle" through new pedagogical approaches aimed at "empower[ing] black children in ways that traditional schools in America historically have not," in part by stressing "black power, pride, and excellence." 67

Nowhere is this more apparent than St. Louis, Missouri. In 2016, a state commission tasked with studying racial inequality in the region issued a report styled Forward through Ferguson that advanced 189 "calls to action" aimed at improving the life outcomes for black children in the city. The document made no mention of racial integration, a remarkable omission given that St. Louis boasted the "largest and longest running school desegregation program" in the country at the time. ${ }^{68}$ That program, sparked by a 1972 lawsuit to desegregate St. Louis public schools, had involved the construction of magnet schools to draw white students into the city, mandatory busing within the city, and a voluntary busing program for black city students interested in attending majority-white suburban schools. ${ }^{69}$

That Forward through Ferguson did not even mention school integration in its report may reflect the busing program's impending phase-out in 2019, or it may represent a larger shift in thinking about race and reform generally, similar to what is happening in New York. For example, recent data released by St. Louis Public Schools suggests that even though students who were bused to suburban districts outperformed their peers in general city schools, city students who remained and accessed the twenty-three "magnet and choice programs" in St. Louis did even better. ${ }^{70}$ Such numbers seem to coincide with a larger shift in thinking about the value of integration generally in the United States, a shift reflected not only in Forward through Ferguson, but also "Vision for Black Lives," a policy platform endorsed by Black Lives Matter in 2016 (which did not

\footnotetext{
${ }^{67}$ Eliza Shapiro, "I Love My Skin!” Why Black Parents are Turning to Afrocentric Schools, N.Y. TIMES, Jan. 8, 2019, A1, A24.

${ }^{68}$ Stephen Deere, Nixon announces members of Ferguson Commission, ST. LouIs PosTDisPatch, Nov. 19, 2014, A1; Elisa Crouch, St. Louis desegregation program headed for phase out, St. Louis Post-DisPatch, June 10, 2016, A1. Forward through Ferguson: A Path Toward Racial Equality (2015) (hereinafter Forward through Ferguson).

${ }^{69} \mathrm{Id}$.

${ }^{70}$ Id. and Eliza Shapiro, "I Love My Skin!" Why Black Parents are turning to Afrocentric Schools, N.Y. TiMES, Jan. 8, 2019, A1, A24.
} 
mention integration), and recent trends in cities like Milwaukee, Chicago and New York, where growing numbers of black parents are opting for "schools explicitly designed for black children."71

At least one third of Forward through Ferguson's 189 calls to action place "youth at the center" of reform, recommending a series of initiatives aimed at providing poor children with the resources and education that they need to move directly, and successfully, into decent paying jobs - minus integration. Currently, $82 \%$ of all children in St. Louis public schools are African American, a number that is even higher for general public schools not designated magnets. For children in non-magnet programs, basic necessities are often lacking, whether adequate housing, school supplies, even nutrition. For example, the report recommends eliminating bureaucratic hurdles to the federal government's Supplemental Nutrition Assistance Program (SNAP) which provides poor children with free or subsidized lunch, a program that over $80 \%$ of St. Louis public school students access. This alone provides a tangible benefit to disadvantaged youth, not to mention a glimpse into the manner in which the report focuses not simply on changing the composition of classrooms (first-order diversity), but providing poor children with resources that their middle and upper middle class peers already have.

Along these lines, the report calls for establishing "school based health centers," capable of providing students with "access to mental health, case management, and reproductive health." ${ }^{, 72}$ Such centers would perform a variety of functions targeting deeper issues of poverty and deprivation. For example, the report mentions classes on "healthy eating," treatment for "behavioral health issues," and "evidence-based trauma-informed training," all services that affluent students would arguably contract for privately, through health insurance. ${ }^{73}$ Student health centers also focus on logistical challenges facing poor families, including time off for doctor's visits and trips to the pharmacy.

\footnotetext{
${ }^{71}$ Yamiche Alcindor, Black Lives Matter Coalition Makes Demands as Campaign Heats Up, N.Y. TIMES, Aug. 1, 2016.

${ }^{72}$ Forward Through Ferguson: A Path to Racial Equity, 40.

${ }^{73}$ Forward Through Ferguson: A Path to Racial Equity, 40.
} 
Beyond health care and lunch programs, the education component of Forward through Ferguson also covers school discipline, a topic that has received considerable attention from scholars interested in the treatment of black students by white teachers. For example, the report notes that $14 \%$ of African American elementary school students in Missouri had suffered school suspensions, while only $1.8 \%$ of white students in Missouri had been suspended. ${ }^{74}$ Part of this gap stemmed from implicit bias among teachers, including black teachers, who were more prone to viewing African American students as "trouble-makers." 75 To address this, the commission recommended "cultural responsiveness and anti-bias training" for educators, an expenditure that may not have received support in a majority white school district. ${ }^{76}$

Forward through Ferguson also recommended early childhood education and job training, including training for parents who have children in early childhood education, an approach that takes into account the reality that many parents living below the poverty line are themselves in need of education, and lack the resources to pay for childcare while going back to school. For primary and secondary school students, the Report recommends integrating "high quality career and technical education (CTE) into the curriculum in part through workbased learning," a type of vocational training geared towards providing low income students with high income jobs. ${ }^{77}$

Looked at broadly, the proposals in Forward through Ferguson go far beyond what conventional notions of public education might entail, a type of coordinated social service delivery system for children, teenagers, and even their adult parents. ${ }^{78}$ That the Ferguson Commission deemed such measures necessary, or at least important enough to include in their Report, is worth underscoring. Collectively, the calls to action regarding education in St. Louis paint a startling portrait of the lives of children in the region. Rather than a population simply lacking daily contact with white youth, the predominantly black children of St.

\footnotetext{
${ }^{74}$ Forward Through Ferguson: A Path to Racial Equity, 40.

${ }^{75}$ Forward Through Ferguson: A Path to Racial Equity, 40.

${ }^{76}$ Forward Through Ferguson: A Path to Racial Equity, 40.

${ }^{77}$ Forward Through Ferguson: A Path to Racial Equity, 129.

${ }^{78}$ Forward Through Ferguson: A Path to Racial Equity, 128.
} 
Louis require a panoply of services that strain the very concept of education itself, including trauma counseling, comprehensive health care, vocational training, food, and even shelter. For example, one section of the report recommends "financial literacy and technical assistance" for Section 8 housing beneficiaries, an end to predatory lending, and a requirement that private developers address the "affordable housing needs of the state, region, and locality where they will be located." 79

Compared to earlier programs aimed at transporting a select number of urban children out of the city, a plan that emphasized the benefits black children might gain from whites, and vice versa (i.e. "first-order diversity"), Forward through Ferguson represents a decidedly "second-order" approach to education in the city. It is not as explicitly Afrocentric as programs in New York, to be sure, but it nevertheless achieves many of the same goals that Gerken identifies. For example, it turns the tables on white implicit bias, hands control to black administrators, allows black teachers the opportunity to dissent by deciding, and provides a host of "calls to action" that are themselves experimental approaches to educating under-privileged youth.

More complicated is the role that second-order diversity might play in higher education, as the next section shall demonstrate.

\section{Second-Order Diversity and Higher Education}

Though liberals tended to celebrate Powell's endorsement of first-order diversity in Bakke, not all proponents of racial equality agreed with his approach. ${ }^{80}$ For example, an African American appointee to the Court named Clarence Thomas took issue with Powell in 1992, deriding first-order diversity as a charade. ${ }^{81}$ Thomas, like Powell, hailed from the South, and possessed a sense of black pluralism not unlike that endorsed by Ralph Ellison and Zora Neale Hurston

\footnotetext{
${ }^{79}$ Forward Through Ferguson: A Path to Racial Equity, 53.

${ }^{80}$ Anders Walker, The Burning House: Jim Crow And the MaKing OF Modern America 221-29 (2018).

${ }^{81} I d$.
} 
in the 1950s. ${ }^{82}$ Thomas shared Hurston's anger at the presumption that African Americans were somehow damaged if they did not go to school with whites, a position that derived from his childhood in Pin Point, Georgia, a majority black township near Savannah that boasted a long tradition of black self-reliance, dating back to the Civil War. ${ }^{83}$ Oddly, this upbringing made Thomas even more sympathetic to the types of arguments that Heather Gerken would later identify as second-order diversity. ${ }^{84}$

To illustrate, Thomas wrote an opinion in 1992 styled United States $v$ Fordice that advocated strongly for Historically Black Colleges and Universities (HBCU's), institutions that Gerken herself has described as examples of secondorder diversity. ${ }^{85}$ Specifically, Thomas maintained that black colleges and universities "exercised leadership in developing educational opportunities for young blacks," and collectively symbolized "the highest attainments of black culture," both arguments that fit nicely into the table-turning, dissent deciding rubric of second-order diversity. Thomas even held that states should be encouraged to "operate a diverse assortment of institutions - including historically black institutions," precisely the type of disaggregated political landscape that Gerken would espouse in her piece, over a decade later. "It would be ironic, to say the least," argued Thomas, "if the institutions that sustained blacks during segregation were themselves destroyed in an effort to combat its vestiges." 86

Thomas conveyed a similar sentiment in a 1995 case brought by the State of Missouri against a lower court order demanding the construction of magnet schools to attract suburban white students into black inner city schools in Kansas City. Styled Missouri v. Jenkins, the case resulted in a majority holding that the district court had exceeded its constitutional bounds, a point that Thomas agreed with. "It never ceases to amaze me," declared Thomas in a concurring opinion,

\footnotetext{
${ }^{82} I d$.

83 J. William Harris, DeEp Souths: Delta, PiEDmont, and Sea Island Society in the Age OF SEGREGATION 11-26 (2001).

${ }^{84}$ Id.

${ }^{85}$ Gerken, Second-Order Diversity, 1108.

${ }^{86}$ United States v. Fordice, 505 U.S. 717, 748 (Thomas J. concurring).
} 
"that the courts are so willing to assume that anything that is predominantly black must be inferior," a clear jab at Brown v. Board of Education. The District's emphasis on luring white students back into the school district struck Thomas as racist, a move rooted in the false presumption that blacks suffered "unspecified psychological harm" simply because they did not rub shoulders with whites, a position that had undergirded the Supreme Court's argument in Brown, but that black intellectuals like Zora Neale Hurston and Ralph Ellison had long taken issue with. To them, and to Thomas, such notions rested on the false "assumption of black inferiority." Thomas maintained that it was simply not the case that "blacks cannot succeed without the benefit of the company of whites," even though this is what the district court had in fact held. Indignant, Thomas applied the same reasoning to primary and secondary schools that he had to historically black colleges and universities, suggesting that "[d] espite their origins in the "shameful history of state-enforced segregation,' these institutions can be 'both a source of pride to blacks who have attended them and a source of hope to black families who want the benefits of ... learning for their children."

Precisely because of his faith in black schools, Thomas went even farther than Powell in endorsing racial pluralism, even to the point of deriding Powell's arguments about diversity in classrooms. As Thomas saw it, Powell's invocation of diversity was little more than a ploy to benefit white students at the expense of blacks. Little pedagogical benefit would inure to black students, argued Thomas, who were accepted into majority white schools for "diversity" purposes rather than grades, for they would find themselves behind academically yet also on display so that white students and white institutions could feel better about themselves. Better, argued Thomas, to send black students to historically black colleges and universities, where they would be free from white micro-aggressions,

\footnotetext{
${ }^{87}$ Missouri v. Jenkins, 515 U.S. 70, 114, 118 (1995); Fordice, 505 U.S. at 748 (Thomas, J., concurring).
} 
free from having to teach white students about the black experience, and statistically more likely to enjoy "higher academic achievement." 88

To frame his opinion in Gerkenian terms, Thomas rejected first-order diversity and praised second, suggesting it provided a better means of advancing black educational interests. Thomas made these points even more clear in a 2003 case styled Grutter v. Bollinger, a challenge to the admissions policy at the University of Michigan Law School, which allowed administrators to take race into account when admitting students with lower than average test scores. Guided by Powell's opinion in Bakke, the policy allowed for the consideration of race as one of several "soft variables" that might be noted in deciding to admit a student with lower scores for the express purpose of achieving "that diversity which has the potential to enrich everyone's education." A white applicant named Barbara Grutter challenged the policy, leading the Court to reassess the role of racial preferences in university admissions. Writing for the majority, Justice Sandra Day O'Connor upheld Powell's designation of diversity as a compelling state interest, but misinterpreted his reasoning by taking diversity to be important primarily as a means of achieving racial equality, a stopgap measure necessary only so long as there were racial disparities in society more generally. ${ }^{89}$ "The requirement that all race-conscious admissions programs have a termination point," reasoned O'Connor, "“assure[s] all citizens that the deviation from the norm of equal treatment of all racial and ethnic groups is a temporary matter, a measure taken in the service of the goal of equality itself." This was a misreading

${ }^{88}$ Grutter v. Bollinger, 539 U.S. 306, 349 (2003) (Thomas J., dissenting). For a more critical take on Thomas's dissent in Grutter, see

${ }^{89}$ In 1992, for example, the nation's highest tribunal ruled in favor of a challenge to historically black colleges in Mississippi, arguing in a case styled United States $v$. Fordice that simply removing express racial bans did not satisfy Brown, a point that cut against Powell's earlier opinions in Keyes and Swann. United States v. Fordice, 505 U.S. 717 (1992). Though the Court would ultimately uphold the sanctity of school district lines, it would subsequently read a very different interpretation of diversity than the one Powell had endorsed in Bakke. See e.g. Missouri v. Jenkins, 515 U.S. 70 (1995). Grutter v. Bollinger, 539 U.S. 306, 314, 316 (2003). See also Kathleen Sullivan, Sins of Discrimination: Last Term's Affirmative Action Cases, 100 HARV. L. REV. 78 (1986) (arguing that the Supreme Court has tended to view diversity programs as "penance for the specific sins of racism a government, union, or employer has committed in the past") 
of Powell, who did not link diversity to equality, and, for precisely that reason, did not believe that diversity should be considered a "temporary matter." As Powell saw it, diversity was a permanent matter because it went to pedagogy, a goal protected by the First Amendment's guarantee of academic freedom. ${ }^{90}$

Though O'Connor did not seem to think that race and pedagogy could be linked permanently, she did defer to the University of Michigan's claim that diversity was "essential to its educational mission" because it promoted "crossracial understanding," broke down "racial stereotypes" and "enable[d] [students] to better understand persons of different races." This was first-order diversity traditionally conceived, tied not just to notions of equity but also to questions of academic freedom, protected by the First Amendment.

Thomas found this insulting. As he saw it, Michigan's plan patronized African Americans and threatened black institutions. Citing Frederick Douglass, he rejected the majority opinion and argued that "blacks can achieve in every avenue of American life without the meddling of university administrators." Whether they went to Michigan or not, argued Thomas, black students' faced the same chances at future success, and may even have done better at black institutions. For example, Thomas cited "growing evidence" that racial "heterogeneity actually impairs learning among black students," and that many African American students "experience superior cognitive development at Historically Black Colleges." This raised a point similar to the one that Thomas had made in Fordice, namely that HBCU's warranted public support, and suffered when black students were siphoned away to majority white flagship schools. For example, Thomas challenged the idea that black students did better when surrounded by white peers, citing historically black institutions like Morehouse College in Atlanta, which boasted only .1\% white students, yet remained "one of the most distinguished HBCs in the Nation," and Mississippi Valley State, which boasted only $1.1 \%$ white students in its 2001 entering freshman class. Neither,

${ }^{90}$ Grutter v. Bollinger, 539 U.S. 306, 342 (2003). 
argued Thomas, suffered from lack of a "critical mass" of white students. In fact, they probably benefitted from it. ${ }^{91}$

Missing from Thomas's analysis were the benefits of diversity. According to the majority opinion in Grutter, these included improving cross-racial understanding, challenging racial stereotypes, and improving classroom discussions, along with more long-term goals like preparing students for work in an 'increasingly diverse' society and "global marketplace." 92 How such goals might be achieved in a majority black college was not clear from Thomas's analysis, nor was it clear that they were the only pedagogical goals diversity might serve.

For example, sociologists Sherri Grasmuck and Jennifer Kim argue that diversity in higher education can, and does, take on at least two different forms: interactive and fragmented. ${ }^{93}$ In the first, interactive mode, students of different races mix in the same spaces and make connections across racial lines - much like the first-order diversity that Grutter describes. ${ }^{94}$ In the second, "fragmented" form, however, students seek out their own spaces and forge bonds with their own racial group - more like Gerken's definition of second-order diversity. ${ }^{95}$

How might "fragmented" diversity benefit pedagogy, if at all? According to Grasmuck and Kim, some minority students gravitate "toward more insular ethnoracial mixing" in college, meaning that they actually cut ties to students from other races. ${ }^{96}$ This was true for minority students who had attended majority

\footnotetext{
${ }^{91}$ Grutter v. Bollinger, 539 U.S. 306, 349, 364, 372 (2003) (Thomas J., dissenting).

${ }^{92}$ Michael J. Kaufman, PICS in Focus: A Majority of the Supreme Court Reaffirms the Constitutionality of Race Conscious School Integration Strategies 35 HASTINGS CONST. L.Q. 1 (2007); Maureen Hallinan, Diversity Effects on Student Outcomes: Social Science Evidence, 59 OHIO ST. L. J. 733, 753 (1998).

${ }^{93}$ Sherri Grasmuck and Jennifer Kim, Embracing and Resisting Ethnoracial Boundaries: SecondGeneration Immigrant and African-American Students in a Multicultural University, 25 SOCIOLOGICAL FORUM 221, 224 (2010).

${ }^{94}$ Sherri Grasmuck and Jennifer Kim, Embracing and Resisting Ethnoracial Boundaries: SecondGeneration Immigrant and African-American Students in a Multicultural University, 25 SOCIOLOGICAL FORUM 221, 224 (2010).

${ }^{95}$ Sherri Grasmuck and Jennifer Kim, Embracing and Resisting Ethnoracial Boundaries: SecondGeneration Immigrant and African-American Students in a Multicultural University, 25 SOCIOLOGICAL FORUM 221, 224 (2010).

${ }^{96}$ Sherri Grasmuck and Jennifer Kim, Embracing and Resisting Ethnoracial Boundaries: SecondGeneration Immigrant and African-American Students in a Multicultural University, 25 SOCIOLOGICAL FORUM 221, 231 (2010).
} 
minority high schools, as well as minority students who had attended majority white high schools. For them, the opportunity to mix with members of their own racial group was a new experience, one that enabled them to learn more about, and feel more comfortable with their racial, ethnic, and/or cultural identity. ${ }^{97}$ As one Indian student put it, "for eighteen years of my life I've been around other people except for Indians." 98 College provided this student with an opportunity to explore contact with her own group, a pedagogical benefit that enabled her to "learn more about myself" and "my culture." "99 Put another way, the opportunity not to mix with whites actually had a positive educational outcome, albeit one not mentioned in Grutter.

Grasmuck and Kim's study suggests that Gerken's notion of second-order diversity might be particularly applicable in majority white schools, for it is in such schools that minority students stand to suffer most from exposure to majority culture, and are therefore interested in seeking out cultural connections and learning experiences within their own group. For them, college becomes less about forging interracial connections, and more about what Grasmuck and Kim call "a rediscovery or reclaiming of a part of themselves that had been unexpressed formerly." ${ }^{100}$ Put in Gerkenian terms, minority students in majority white schools may prize majority-minority spaces more than their white peers, for such spaces provide them with opportunities to "turn the tables" on majority assimilation, dissent by deciding new ways to explore plural identities, and "cycle" through new ways of thinking about and engaging with their own cultural traditions.

Grasmuck and Kim found this to be particularly important for African American students, particularly African American students from middle class backgrounds. According to Grasmuck and Kim, "some [black students] described shifting from a less black precollege social world to a more black space once at the university, in part to "discover[] new things" about themselves, but also to

\footnotetext{
${ }^{97}$ Id. at 231.

98 Id. at 231.

${ }^{99}$ Id. at 231.

${ }^{100}$ Id. at 232.
} 
find "comfort and support."101 Support did not factor into the Supreme Court's analysis in Grutter, yet Grasmuck and Kim both found that black students in majority white institutions tended to suffer varying levels of harm in white dominated spaces, whether from micro-aggressions, implicit bias, or outright bigotry, all reasons to carve out black spaces in majority white institutions. ${ }^{102}$

While Clarence Thomas might conclude that black students should simply avoid white universities and opt for historically black colleges, not all black collegians agree. At Harvard, for example, African American students voice pride in the myriad advantages that come with enrolling at one of the nation's most prestigious universities, even as they seek to carve out majority black spaces within that university. To take just a few examples, African American students at Harvard held their first "black graduation" ceremony in 2017, an event put on by the Harvard Black Students Association and the Harvard Black Graduate Student Alliance to "honor the achievements of black graduating students."103 Maligned by interactive pluralists, the ceremony echoed many of the claims made by the minority students that Grasmuck and Kim surveyed in their study of a large predominantly white public university. For example, black students voiced their frustration with life at Harvard in 2017, noting in the Harvard Crimson that the experience exacted a "toll" on African Americans students in the form of microaggressions, implicit bias, and outright rejection. ${ }^{104}$ "If you're a black Harvard student, you will likely at some point feel like Harvard isn't meant for you," wrote one student, "that you would have been happier somewhere else." 105

To counter such feelings, African American students at Harvard have formed institutions and spaces dedicated to black student life. "The dozen or so active black student organizations were all created," wrote a cadre of black

\footnotetext{
${ }^{101}$ Id. at 232.

102 Id. at 232.

${ }^{103}$ Eryn Mathewson, Don't hate on black graduation ceremony at Harvard University, The Undefeated.com, May 23, 2018.

${ }^{104}$ Ata D. Amponsah, et al. Op-Ed: Welcome to the Harvard Black Community, HARVARD CRIMSON, September 11, 2017.

${ }^{105}$ Ata D. Amponsah, et al. Op-Ed: Welcome to the Harvard Black Community, HARVARD CRIMSON, September 11, 2017.
} 
students, "so black students could find homes in them. ${ }^{106}$ These include "Kuumba, BlackCAST, and KeyChange," all of which aimed at promoting "black voices and creativity" in the arts, as well as pre-professional organizations like the Harvard Society of Black Scientists and Engineers, the Black Law Students Association, the Black Pre-Law Association, and the Harvard Business School's Black Student Union. Such organizations all provided "support," the students maintained, in their struggle against micro-aggressions, implicit bias, and overt prejudice. That such students might want their own graduation ceremony struck Fanta Cherif, head of the 2018 Black Graduation Committee at Harvard, as obvious, something "that every PWI [predominantly white institution] should have." 107

How do we assess such events, and the black-centric institutions that sponsor them? One obvious conclusion is that there may be a place for secondorder diversity within majority white institutions after all - and that such diversity is actually evolving organically on campus. As Grasmuck and Kim note, "[a] strong theme of "born-again ethnicity," ran through the testimonies of minority students who had accessed second-order diversity in majority institutions, as well as "a transformed racial identity - more optimistic, more gay, more political," than the identity that they brought to college. ${ }^{108}$ Such pedagogical benefits are worth flagging. Though not all the African American students surveyed by Grasmuck and Kim prized "fragmented pluralism," the two sociologists found that black students were more likely to reject "interactive pluralism" than their minority peers, a point that seems to go to the heart of the diversity debate in America today. If, for example, schools like Harvard maintain that diversity is a viable pedagogical interest because it breaks down stereotypes and builds crossracial understanding through interactive pluralism, how can it then explain the popularity of fragmented pluralism among the very minority students that it is invoking the use of race to admit?

\footnotetext{
${ }^{106}$ Ata D. Amponsah, et al. Op-Ed: Welcome to the Harvard Black Community, HARVARD CRIMSON, September 11, 2017.

${ }^{107} \mathrm{Id}$.

${ }^{108}$ Id. at 233.
} 
Harvard's pleadings in SFFA v. Harvard provide little by way of explanation. According to documents filed by the university in the case, diversity serves the pedagogical goals listed in Grutter because it places students of races together in the same classes, dining halls, and dorms, thereby achieving the very forms of interactive pluralism long associated with first-order diversity. To the extent that the university recognizes the potential harm that might accrue to minority students in majority settings, it calls for the enrollment of a "critical mass" of minority students, a goal that the Supreme Court approved in Grutter. However, Grutter's approval of critical mass has little to do with second-order diversity. As proponents of the theory explain it, critical mass enhances crossracial discussions, improves cross-racial understanding, and helps break down racial stereotypes; but does not necessarily mean the creation of majority-minority spaces, nor does it imagine that minority students will cut ties with their majority peers for reasons of self-discovery, and cultural enrichment. "With a critical mass of students of the same race," writes Dawinder Sidhu, "those students will feel comfortable articulating their individual perspectives and opinions" - in classes full of whites. ${ }^{109}$ "As a result, [minority students] will break down preconceived notions that members of racial communities share monolithic or predictable positions." 110

Missing from Harvard's pleadings, and from the discussion of diversity in higher education generally, is an appreciation for the role that second-order diversity might play in colleges and universities. And yet, evidence points strongly to all four of the goals that Gerken identifies. For example, second-order diversity provides minorities with "control over some subset of decisions, allowing them to exert the type of power usually reserved for the majority." 111 This, Grasmuck and Kim suggest, is important for minority students tired of implicit bias, micro-aggressions, and outright hostility. Once in minority spaces, they can control what happens in those spaces, obviating harm and exploring

${ }^{109}$ Dawinder S. Sidhu, A Critical Look at the 'Critical Mass' Argument, The CHronicle OF Higher EdUCATION, Feb. 18, 2013.

${ }^{110}$ Dawinder S. Sidhu, A Critical Look at the 'Critical Mass' Argument, The Chronicle of HigHER EDUCATION, Feb. 18, 2013.

${ }^{111}$ Gerken, Second-Order Diversity, 1104. 
subjects that may be of little, if any interest to majorities. Rather than seek to influence those majorities, minority students can simply turn the tables on them, raise new concerns, establish new priorities, and even challenge majority preconceptions, without having to fear majority backlash. ${ }^{112}$

This is particularly true when majority spaces are elevated to the level of academic departments. Far beyond student organizations or student sponsored events, academic departments like Black Studies institutionalize second-order diversity. ${ }^{113}$ As historian Martha Biondi has observed, Black Studies "was part of an intentional effort to redefine the terms of integration: away from assimilation into a Eurocentric institution and toward the restructuring of that institution and its mission." 114 Though some lobbied for Black Studies programs, rather than full departments, proponents of the department idea cited the increased "control" that came with departmental status, a core aspect of second-order diversity. ${ }^{115}$

Central to departmental control was curricula, a topic that generated widespread controversy. Critics charged that Black Studies "lacked curricular coherence" and "failed to meet the definition of a discipline," in part because it lacked a unified methodology. ${ }^{116}$ However, supporters countered that the focus on a single topic, the African American experience, allowed for a certain amount of experimentation and cross-pollination, a rare chance to see how multiple disciplines, whether history, anthropology, sociology and/or literature could be brought to together to better understand the construction, and de-construction of race. ${ }^{117}$ According to Biondi, "most scholars in African American studies reject the effort to impose a single methodology, seeing it as unrealistic and stifling."

\footnotetext{
${ }^{112}$ Gerken, Second-Order Diversity, 1104.

${ }^{113}$ Fabio Rojas, Social Movement Tactics, Organizational Change and the Spread of AfricanAmerican Studies, 84 SocIAL FORCES 2147, 2151 (2006).

${ }^{114}$ Martha Biondi, Controversial Blackness: The Historical Development \& Future Trajectory of African American Studies 2 RACE, INEQUALITY \& CUlTURE 226, 227 (2011).

${ }^{15}$ Martha Biondi, Controversial Blackness: The Historical Development \& Future Trajectory of African American Studies 2 RACE, INEQUALITY \& CULTURE 226, 229 (2011).

${ }^{116}$ Martha Biondi, Controversial Blackness: The Historical Development \& Future Trajectory of African American Studies 2 RACE, INEQUALITy \& Culture 226, 229 (2011).

${ }^{117}$ Martha Biondi, Controversial Blackness: The Historical Development \& Future Trajectory of African American Studies 2 RACE, INEQUALITY \& CUlTURE 226, 229 (2011).

${ }^{118}$ Martha Biondi, Controversial Blackness: The Historical Development \& Future Trajectory of African American Studies 2 RACE, INEQUALITy \& Culture 226, 231 (2011).
} 
The interdisciplinary nature of Black Studies provides a good example of what Gerken terms "cycling," i.e. a process of pedagogic experimentation facilitated by the creation of academic majority-minority space. At Ohio State, for example, Black Studies courses are organized chronologically "with a literary bent," while at Duke University Black Studies takes a cultural studies approach. ${ }^{119}$ At the University of Pennsylvania, African American Studies "filters everything through a W.E.B. Du Bois lens," while New York University "combines pan-Africanism with urban studies." 120 Such hybrid approaches lend themselves to a rigorous interpretation, and re-interpretation, of racial identity, allowing the very concept of race itself to be interrogated, challenged, and explored in a manner unlikely to be rivalled in departments where race is not a focal point. ${ }^{121}$

Black Studies may contribute to another goal as well, what Gerken terms "democratic visibility." 122 Without minority spaces, she argues, it is possible that minority voices will consistently be drowned out by majority consensus, and critical insights into democratic systems missed. For example, the African American interpretation of American history has frequently been ahead of white majority interpretations, particularly on questions like slavery, Reconstruction, and Jim Crow. For decades after the Civil War, the most accurate account of Reconstruction belonged to W.E.B. Du Bois, who was employed at Atlanta Clark University, a segregated school. White institutions like Columbia, Harvard, and Yale, by contrast, taught their students that African Americans were inferior and

${ }^{119}$ Martha Biondi, Controversial Blackness: The Historical Development \& Future Trajectory of African American Studies 2 RACE, INEQUALITY \& CultuRe 226, 230 (2011).

${ }^{120}$ Martha Biondi, Controversial Blackness: The Historical Development \& Future Trajectory of African American Studies 2 RACE, INEQUALITY \& CultuRE 226, 230 (2011).

${ }^{121}$ Gerken, Second-Order Diversity, 1110, citing "[a] number of important, often overlapping literatures [that] have explored the fluidity of identity categories, including strands of antiessentialism critiques, intersectionality, [and] Critical Race Theory.” See, e.g. Ian F. Haney López, The Social Construction of Race: Some Observations on Illusion, Fabrication, and Choice, 20 Harv. C.R.-C.L. L. Rev. 1, 20-39 (1994); Angela P. Harris, Race and Essentialism in Feminist Legal Theory, 42 Stan. L. Rev. 581, 584 (1990); Dan R. Ortiz, Categorical Community, 51 Stan. L. Rev. 769, 804-05 (1999).

${ }^{122}$ Gerken, Second-Order Diversity, 1123. 
that Reconstruction was a mistake, a version of history that went un-debunked until the 1960s. ${ }^{123}$

Of course, this raises the question whether Black Studies' programs can, or should, influence admissions policy. According to Harvard University, for example, black student enrollment would drop from $16 \%$ to $6 \%$ were it to move towards race-blind admissions. Could African American Studies argue that such numbers might be insufficient to sustain legitimate pedagogical goals, and therefore race needs to be considered in admissions? Gerken suggests yes. For example, Black Studies faculty could argue that there is pedagogical value in majority black classrooms, either because they allow black students to speak more freely (dissent by deciding), focus on different critical topics (turn the tables on majorities), and/or experiment with different thematic ideas (cycling). Such students, Harvard could argue, may find that majority-minority classrooms advance pedagogical goals different from, but just as important as, statistically integrated classes.

Pursuant to Regents v. Bakke, this would qualify as a compelling constitutional interest. $^{124}$ In that case, Supreme Court Justice Lewis F. Powell, Jr. held that race could be used in university admissions so long as it served a sincere pedagogical goal, related to diversity. ${ }^{125}$ Though scholars and judges assumed that Powell meant first-order diversity, Powell recognized the value of secondorder diversity as well. ${ }^{126}$ For example, he celebrated same-sex colleges as an example of diversity (places where women could dissent by deciding), as well as private schools, parochial schools, and other institutions where intellectual, political, or religious minorities might act as majorities. ${ }^{127}$ These were all examples of second-order diversity writ large, to be sure, but they suggest that Powell understood diversity to mean more than simply statistical integration.

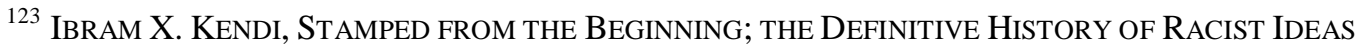
IN AMERICA 286-287 (2016).

${ }^{124}$ Regents v. Bakke, 438 U.S. 265, 311-12 (1978).

${ }^{125}$ Regents v. Bakke, 438 U.S. 265, 311-12 (1978).

${ }^{126}$ ANDERs Walker, The Burning House: Jim Crow AND the MaKing OF Modern AMERICA 193-95 (2018).

${ }^{127}$ ANDERS WALKer, THE BURNING House: Jim CROW AND THE MAKING OF MODERN AMERICA 189-90, 192 (2018).
} 


\section{CONCLUSION}

The role that diversity has played vis a vis schools has never been fully understood. As this article has sought to demonstrate, Brown v. Board of Education did not recognize diversity as a relevant constitutional concept, and in many ways discounted it. Relying on Gunnar Myrdal's conclusion that black America was pathological, Brown declared assimilation, not difference, to be the solution to America's racial "dilemma," a move rejected by many - white and black - in the American South. Justice Lewis F. Powell, Jr. expressed this view by elevating diversity to the level of a constitutional interest in Regents v. Bakke, a decision that liberals and conservatives alike misunderstood - falsely equating the concept to statistical integration.

Heather Gerken provides us with a way out of this quandary, and with a way to think about schools in a post-Brown era marked by retrenchment and reaction. For school districts that have re-segregated due to white flight, for example, Gerken's theory of second-order diversity provides us with a new way of thinking about primary and secondary education, focusing on the needs of minority students in majority-minority settings. Already, education reformers in groups like Forward through Ferguson and Black Lives Matter have begun down this road, rejecting integration as a relevant policy goal.

Integration also seems less imperative to higher education. Liberal reformers like Black Lives Matter and conservative voices like Clarence Thomas have both voiced a recommitment to majority-minority education in the form of historically black colleges and universities. Meanwhile, minority students at majority white institutions have worked diligently to carve out their own spaces, including their own student organizations, their own events, and - after dogged protest - their own academic departments. Perhaps no department is a better example of this than Black Studies.

Harvard made no reference to Black Studies in a recent report that it filed on the benefits of diversity, positing instead that the school sought to "improve 
the opportunities we offer our students to engage with others in an exploration and challenge of their ideas and beliefs." ${ }^{128}$ That engaging with others might not appeal to minority students, particularly those who had engaged with majority students in high school and suffered for it, did not seem to be on Harvard's radar. For example, the school explained that its students arrived "with their identities partially formed, shaped by racial, ethnic, social ... and other cultural factors," but left with an "additional identity, that of membership in 'the community of educated men and women," that was "inclusive of, but not bounded by race or ethnicity." 129 That some students might actually deepen their racial and cultural identities at college, as Grasmuck and Kim found, did not factor into Harvard's analysis.

By failing to apply second-order diversity to schools, Harvard failed to capture the reality of diversity as it is experienced on its own campus, and missed an opportunity to explain why that form of diversity is linked to pedagogy. For example, it failed to mention that fragmented pluralism is a real phenomenon at Harvard, and that it may be a good thing, allowing minorities to control their own spaces, turn the tables on majorities, dissent by deciding, and cycle through different pedagogical approaches. Said goals might benefit minority students by releasing them from the pressures of micro-aggressions, implicit bias, and outright rejection. Meanwhile, such programs might also benefit majority students who choose to take Black Studies courses. For them, the experience of sitting in a classroom where they are not a member of the majority might be a valuable learning experience, perhaps even more valuable than sitting in a classroom where they play a dominant role.

\footnotetext{
${ }^{128}$ Rakesh Khurana, et al. Report of the Committee to Study the Importance of Student Body Diversity, 5.

${ }^{129}$ Rakesh Khurana, et al. Report of the Committee to Study the Importance of Student Body Diversity, 5.
} 